\title{
Melatonin inhibits TPA-induced oral cancer cell migration by suppressing matrix metalloproteinase- 9 activation through the histone acetylation
}

\author{
Chia-Ming Yeh ${ }^{1}$, Chiao-Wen Lin ${ }^{2,3}$, Jia-Sin Yang ${ }^{1,4}$, Wei-En Yang ${ }^{1,4}$, Shih-Chi Su ${ }^{5}$, \\ Shun-Fa Yang ${ }^{1,4}$ \\ ${ }^{1}$ Institute of Medicine, Chung Shan Medical University, Taichung, Taiwan \\ ${ }^{2}$ Institute of Oral Sciences, Chung Shan Medical University, Taichung, Taiwan \\ ${ }^{3}$ Department of Dentistry, Chung Shan Medical University Hospital, Taichung, Taiwan \\ ${ }^{4}$ Department of Medical Research, Chung Shan Medical University Hospital, Taichung, Taiwan \\ ${ }^{5}$ Whole-Genome Research Core Laboratory of Human Diseases, Chang Gung Memorial Hospital, Keelung, Taiwan \\ Correspondence to: Shun-Fa Yang, e-mail: ysf@csmu.edu.tw
}

Keywords: melatonin, oral cancer, MMP, CREBBP, EP300

Received: December 18, 2015

Accepted: February 23, 2016

Published: March 09, 2016

\section{ABSTRACT}

Melatonin exerts antimetastatic effects on liver and breast cancer and also inhibits matrix metalloproteinase (MMP) activity. However, the detailed impacts and underlying mechanisms of melatonin on oral cancer cell metastasis are still unclear. This study showed that melatonin attenuated the 12-0-tetradecanoylphorbol-13acetate-induced migration of oral cancer cell lines, HSC-3 and OECM-1. Zymography, quantitative real-time PCR, and Western blotting analyses revealed that melatonin lessened MMP-9 enzyme activity as well as the expression of MMP-9 mRNA and protein. Furthermore, melatonin suppressed the phosphorylation of the ERK1/2 signalling pathway, which dampened MMP-9 gene transcription by affecting the expression of transcriptional coactivators, such as CREB-binding protein (CREBBP) and E1A binding protein p300 (EP300), and decreasing histone acetylation in HSC-3 and OECM-1 cells. Examinations on clinical samples exhibited that MMP-9, CREBBP, and EP300 were significantly increased in oral cancer tissues. Moreover, the relative level of CREBBP was positively correlated with the expression of MMP-9 and EP300. In conclusion, we demonstrated that melatonin inhibits the motility of HSC-3 and OECM-1 cells in vitro through a molecular mechanism that involves attenuation of MMP-9 expression and activity mediated by decreased histone acetylation.

\section{INTRODUCTION}

Head and neck cancer is a common human cancer, and approximately $50 \%$ of cases occur in the oral cavity; more than $90 \%$ of these cases involve oral squamous cell carcinoma (OSCC) [1]. Cancer cell migration is increased by matrix degrading proteinases, integrins, and other cell adhesion molecules. Extracellular matrix (ECM) degradation is crucial in cancer invasion and metastasis because the metastasis of cancer cells requires the destruction of mesenchymal collagen or the spreading of the endothelial basement membrane to the surrounding tissue [2]. Thus, inhibition of ECM degradation by proteinases, such as matrix metalloproteinases (MMPs), and plasminogen activators is considered as critical in cancer therapy [3-5].

Numerous studies have revealed that MMPs are overexpressed in several types of malignant tumours, including oral cancer [6-8]. Of the MMPs, MMP-2 and MMP-9, known as the gelatinases that degrade the main constituent of the basement membrane and type IV collagen, have been recognised as crucial in cancer invasion and metastasis. Previous studies have revealed that inhibiting the activity of MMP-2 and MMP-9 reduces 
cancer cell metastasis [3, 5, 9-13]. However, the detailed effects of melatonin on oral cancer cell metastasis and MMP expression as well as the mechanisms by which these effects occur are still unclear.

Melatonin, also known as N-acetyl-5-methoxytryptamine, is synthesized from tryptophan via 5-hydroxytryptamine [14]. This hormone is crucial in regulating the immune system [15] and is a potent antioxidant agent $[16,17]$. Other studies show that melatonin is a natural oncostatic agent, which protects humans from malignant neoplasms [18-20]. Previous studies have revealed that melatonin inhibits the growth and metastasis of breast cancer, cervical cancer, and ovarian cancer cells [21-23]. Recently, several studies have indicated that melatonin can decrease the expression of MMPs [24] and inhibit the invasion and metastasis of cancer cells [25-27]. For oral cancer, Goncalves et al. showed that melatonin inhibits cell viability in the oral carcinoma and inhibits the angiogenesis [28]. Reiter et al. also concluded that endogenously-produced and exogenously-applied melatonin are beneficial to the oral cavity [20]. The results indicate that melatonin in the oral cavity are likely to relate primarily to its anti-inflammatory and antioxidant activities [20]. However, few data regarding the antimetastatic potential of melatonin on oral cancer cells are available. Thus, this study examined the effects of melatonin with potential antimetastatic properties in 12-O-tetradecanoylphorbol-13- acetate (TPA)-treated HSC-3 and OECM-1 human oral cancer cells in vitro to investigate the signalling pathway of this process.

\section{RESULTS}

\section{Effects of melatonin on the viability of HSC-3 and OECM-1 cells}

We measured cell viability by using various concentrations $(0,0.5$, and $1 \mathrm{mM})$ of melatonin for $24 \mathrm{~h}$ by MTT assay to investigate the cytotoxicity of melatonin on HSC-3 and OECM-1 cells. Melatonin demonstrated no significant toxicity on the TPA-treated and untreated HSC-3 and OECM-1 cells at concentrations between 0 and $1 \mathrm{mM}$ for $24 \mathrm{~h}$ (Figure 1A). The range of concentrations was explored in subsequent experiments.

\section{Effects of melatonin on migration of HSC-3 and OECM-1 cells}

The antimetastatic activity of melatonin on HSC-3 and OECM-1 was measured through the migration assay by using the transwell. The results show that TPA treatment resulted in a noticeable increase in cell migration, whereas melatonin inhibited the TPA-induced cell migration in a dosedependent manner (Figure 1B). Collectively, these results indicate that melatonin effectively prevented TPAinduced migration in the HSC-3 and OECM-1 cells.

\section{Effects of melatonin on MMP-9 enzyme activity, protein expression, and mRNA expression}

The gelatin zymography assay was used to investigate the effect of melatonin against the MMP-9 enzymatic activity in HSC-3 and OECM-1 cells following TPA treatment. Melatonin was found to significantly reduce TPA-induced MMP-9 gelatinolytic activity through gelatin zymography (Figure 2A). The results also demonstrated that melatonin treatment resulted in a reduction in TPA-induced intracellular expression of MMP9 (Figure 2B). Reverse transcription polymerase chain reaction (RT-PCR) and quantitative real timePCR (qPCR) was then used to investigate the effect of melatonin treatment on the regulation of TPA-induced MMP9 transcription. Melatonin treatment resulted in a reduction in the MMP9 mRNA expression levels in a dosedependent manner (Figure 2C). QPCR also demonstrated a TPA-induced increase in MMP-9 mRNA expression in HSC-3 and OECM-1 cells as well as suppression of this increase for melatonin treatment. These results indicate that melatonin suppresses TPA-induced MMP-9 expression at the protein and mRNA levels and that the compound inhibits the enzymatic activity of MMP-9.

\section{Effects of melatonin on MAPK pathways}

After the inhibitory effects of melatonin on cell migration and MMP-9 expression were revealed, the effects of melatonin on the expression of mitogen activated protein kinase (MAPK) pathways were investigated to elucidate their underlying mechanisms. Western blotting revealed that TPA significantly increased the phosphorylation of three MAPK pathways in HSC-3 and OECM-1 cells. Furthermore, melatonin reduced the phosphorylation of ERK1/2 in HSC-3 and OECM-1 cells, but not the phosphorylation of the JNK and p38 pathways (Figure 3A). To further determine whether melatonin inhibition of MMP-9 activity was caused mainly by the inhibition of the ERK1/2 signalling pathway, the effects of melatonin on a specific inhibitor of the ERK1/2 (U0126) in HSC-3 and OECM-1 cells were investigated. In the gelatin zymography assay, TPA-induced MMP-9 activity of HSC-3 and OECM-1 cells was significantly reduced by the ERK1/2 inhibitor (U0126) (Figure 3B), and the result of the migration assay was similar to that of the gelatin zymography assay (Figure 3C). Moreover, these results revealed that a combined treatment of the ERK1/2 inhibitor (U0126) and melatonin further reduced MMP-9 expression. Thus, inhibiting ERK1/2 signalling pathways might result in reduced MMP-9 expression. 

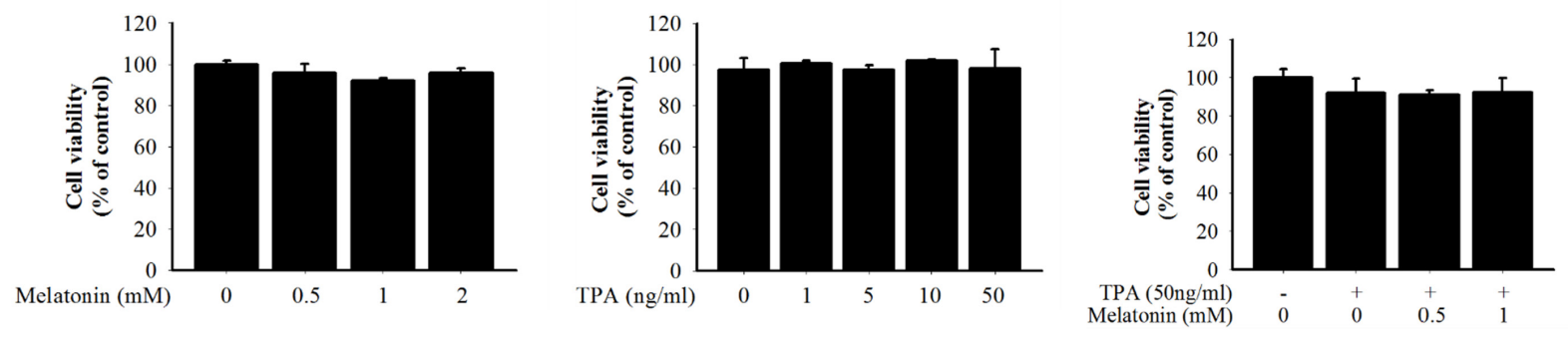

OECM-1
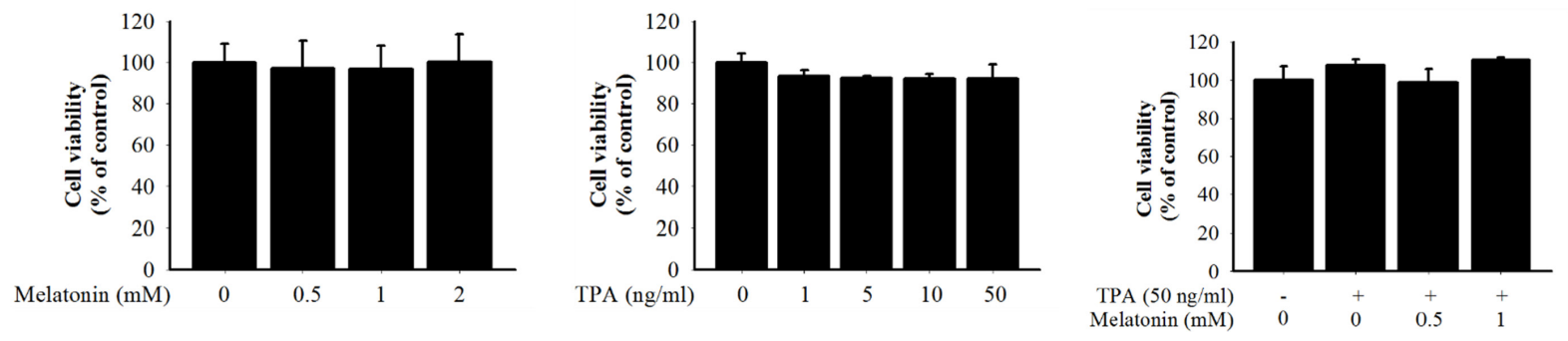

B

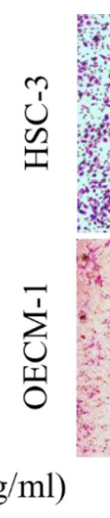

TPA $(50 \mathrm{ng} / \mathrm{ml})$

Melatonin (mM)

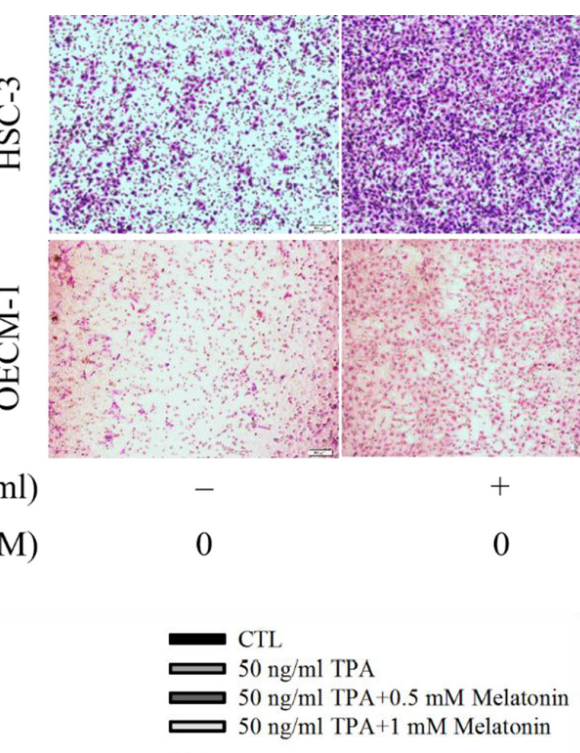

HSC-3
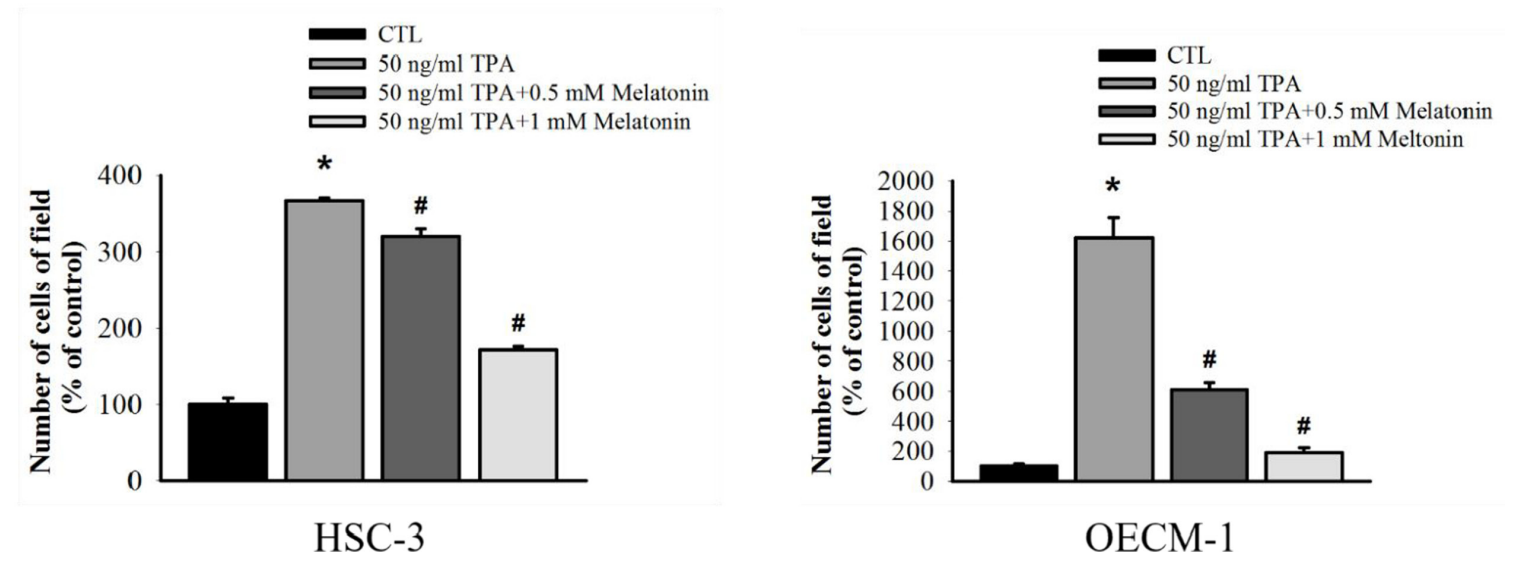

Figure 1: Effect of melatonin on cell migration in HSC-3 and OECM-1 cell. (A) HSC-3 and OECM-1 cells were treated with TPA $(0,1,5,10$, and $50 \mathrm{ng} / \mathrm{mL})$ and melatonin $(0,0.5,1$, and $2 \mathrm{mM})$ for $24 \mathrm{~h}$ before a MTT assay for cell viability. The values are means $\pm \mathrm{SD}$ of at least three independent experiments. (B) Cell migration was measured using transwell for $24 \mathrm{~h}$ (OECM-1 cell) and $48 \mathrm{~h}$ (HSC-3 cell) with polycarbonate filters, respectively. The migration abilities of HSC-3 and OECM-1 cells were quantified by counting the number of cells that invaded the underside of the porous polycarbonate, as described in the Materials and Methods. The values represent the means $\pm \mathrm{SD}$ of at least three independent experiments. ${ }^{*} p<0.05$ compared with the vehicle group; ${ }^{*} p<0.05$ compared to the TPA treatment group. 
A
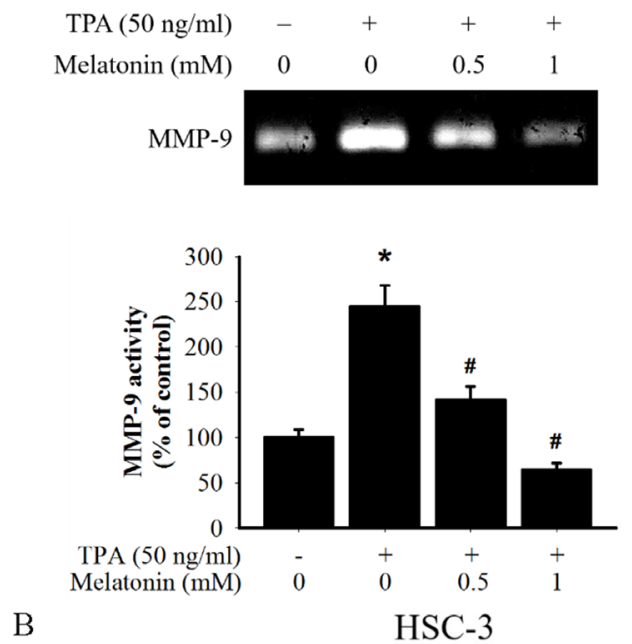

$\mathrm{B}$
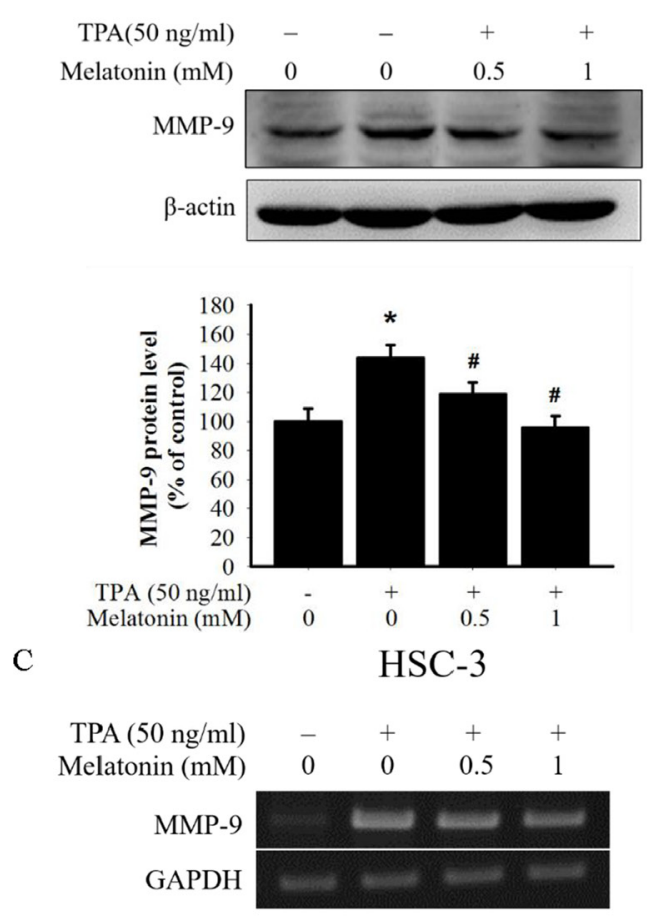

Real-time PCR

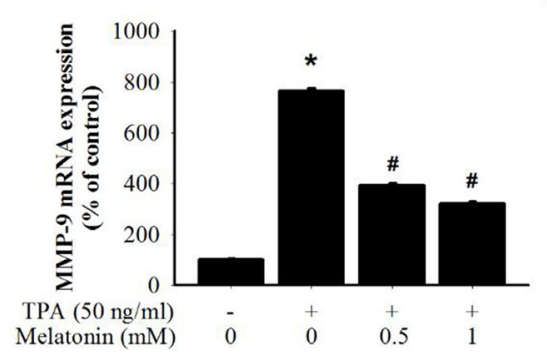

OECM-1
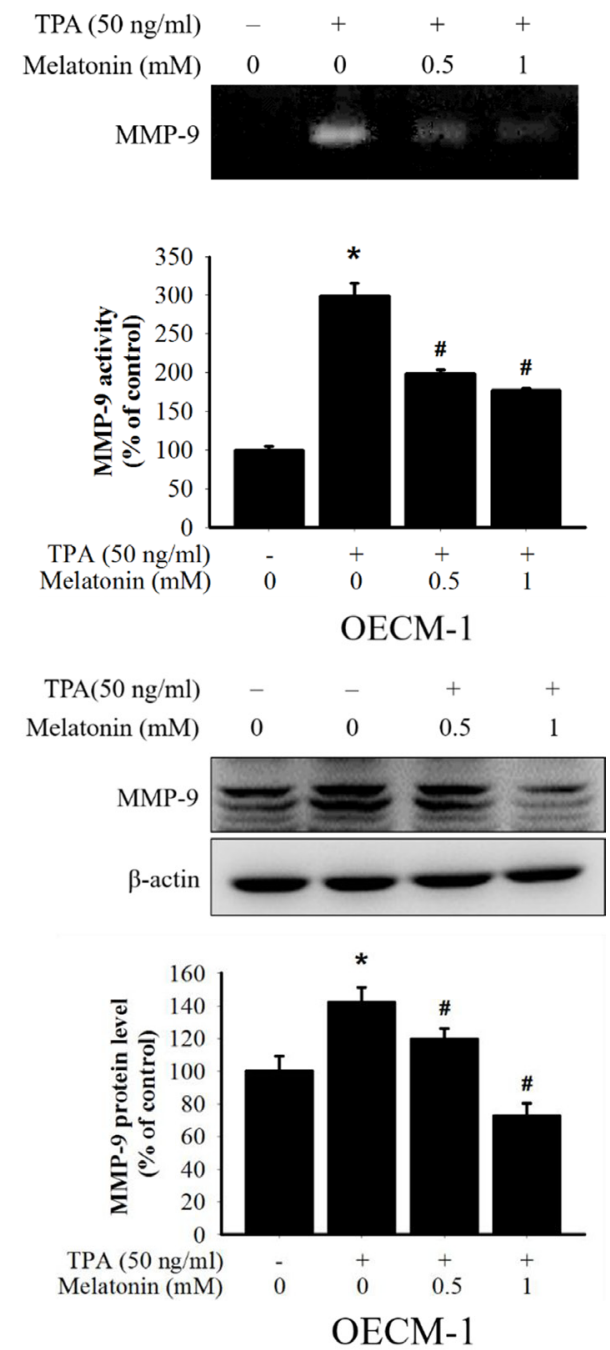

$\begin{array}{rcccc}\mathrm{TPA}(50 \mathrm{ng} / \mathrm{ml}) & - & + & + & + \\ \text { Melatonin }(\mathrm{mM}) & 0 & 0 & 0.5 & 1\end{array}$

MMP-

GAPDH $\Leftrightarrow$

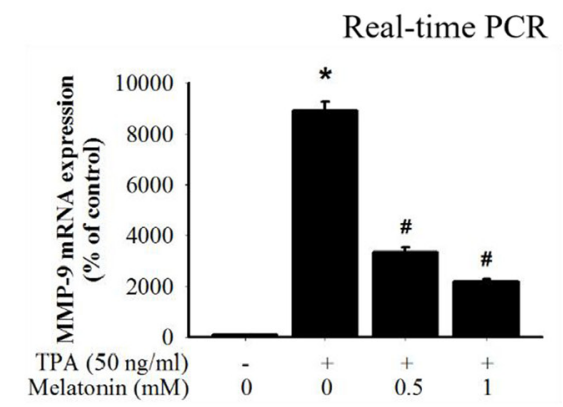

Figure 2: Effects of TPA and melatonin on MMP-9 activity, protein, and mRNA level. (A) HSC-3 and OECM-1 cells were treated with TPA $(50 \mathrm{ng} / \mathrm{mL})$ and melatonin $(0,0.5$, and $1 \mathrm{mM})$ for $24 \mathrm{~h}$ and then subjected to gelatin zymography analysis to determine the activities of MMP-9, (B) or western blotting to analyze the protein levels of MMP-9. (C) The mRNA expression of MMP-9 was analyzed by RT-PCR and Quantitative real time-PCR (qPCR). The values represented the means \pm SD of at least three independent experiments. ${ }^{*} p<0.05$ compared to the vehicle group; ${ }^{*} p<0.05$ compared to the TPA treatment group. 


\section{Melatonin does not inhibit the activation of the NF-кB pathways}

Previous studies have demonstrated that transcription factor $\mathrm{NF \kappa B}, \mathrm{AP}-1$, and $\mathrm{SP}-1$ are crucial in TPA-induced MMP9 gene transcription [29]. Thus, the effects of melatonin on the NFKB, AP-1, and SP-1 signalling pathways were assessed in this study. The Western blotting analysis demonstrated TPA-induced phosphorylation of IкB $\alpha$ in OECM-1 cells, but this was not prevented by melatonin treatment (Figure 4A). In addition, melatonin did not reduce the phosphorylated NFkB p65, AP-1 and SP-1 induced by TPA (Figure 4A). Moreover, the effect of melatonin on the binding of these transcription factors to MMP-9 promoters, which was measured using the luciferase report assay, was not obvious (Figure 4B). Some studies have indicated that ERK1/2 signalling increases the expression of transcriptional coactivator CREB-binding protein (CREBBP) and its paralog E1Abinding protein (EP300) $[30,31]$. To further determine the coactivator factor, CREBBP and EP300, which participate in regulating MMP-9 transcription through ERK1/2 signalling, the immunoprecipitation assay was used. The results revealed that activated ERK1/2 had binding affinities to EP300 and CREBBP protein and melatonin significantly repressed the binding affinities (Figure 4C). Moreover, the results of Western blotting showed that the expression of TPA-induced CREBBP and EP300 were inhibited by melatonin (Figure 4D). We further performed the chromatin immunoprecipitation (ChIP) assay to investigate the involvement of these coactivators in the transcriptional inhibitory effects of melatonin on MMP-9. As illustrated in Figure 4E, the binding ability of CREBBP and EP300 to the MMP-9 promoter was decreased in HSC-3 and OECM-1 cells following melatonin treatment.

To further determine whether melatonin inhibition of MMP-9 expression and oral cancer cell migration was caused mainly by the inhibition of the CREBBP/ EP300 signalling pathway, the effects on a specific siRNA of CREBBP and EP300 in HSC-3 and OECM-1 cells were investigated. In the RTPCR assay, TPA-induced MMP-9 mRNA expression of HSC-3 and OECM-1 cells was significantly reduced by the CREBBP and EP300 siRNA (Figure 5A), and the result of the migration assay was similar to that of the RT-PCR assay (Figure 5B). These results indicate that melatonin suppresses TPA-induced MMP-9 expression by reducing the CREBBP/EP300 but not NF- $\mathrm{KB}$ signalling pathway in HSC-3 and OECM-1 cells.

Previous studies have demonstrated that CREBBP/ EP300 acetylates histones, resulting in chromatin remodelling and relaxation of the chromatin structure to enable transcription $[32,33]$. Thus, the effects of melatonin on histone acetylation were also assessed in this study. Western blotting revealed that TPA significantly

A

HSC-3

OECM-1

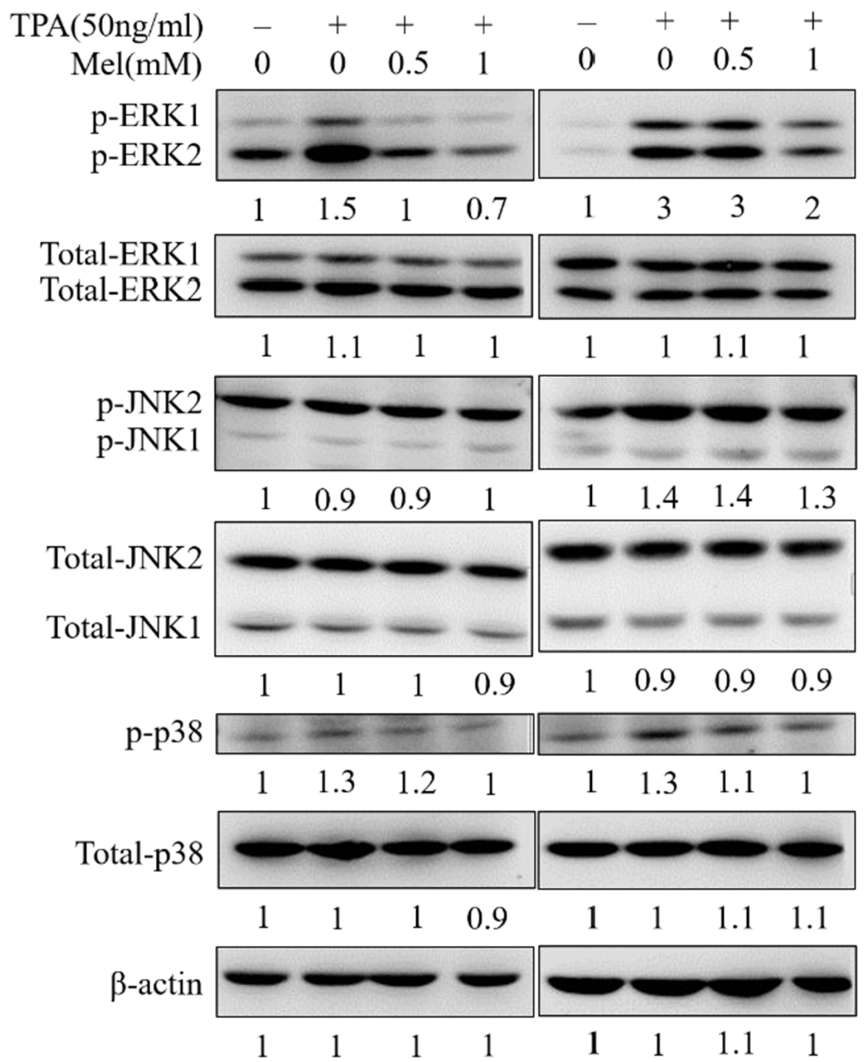



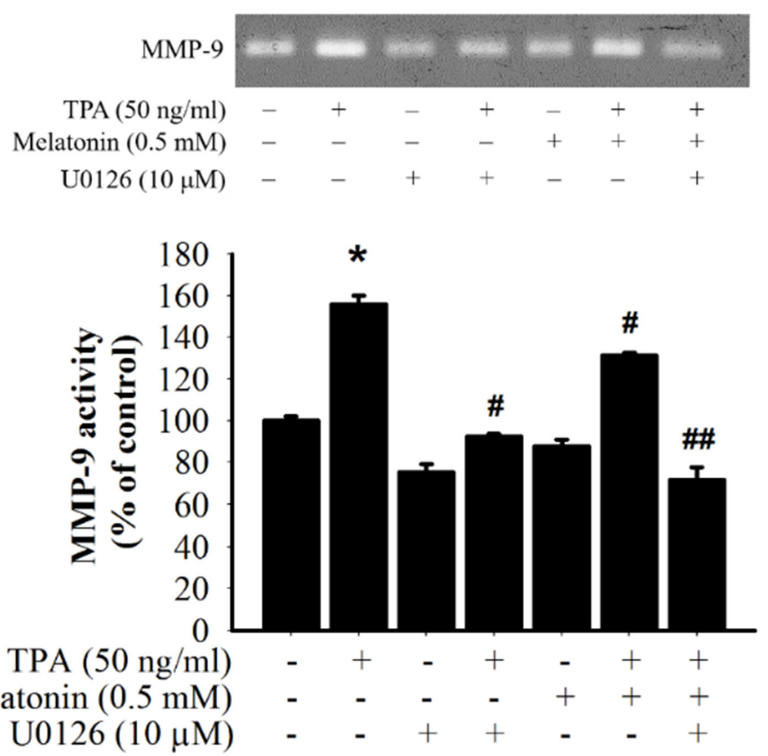
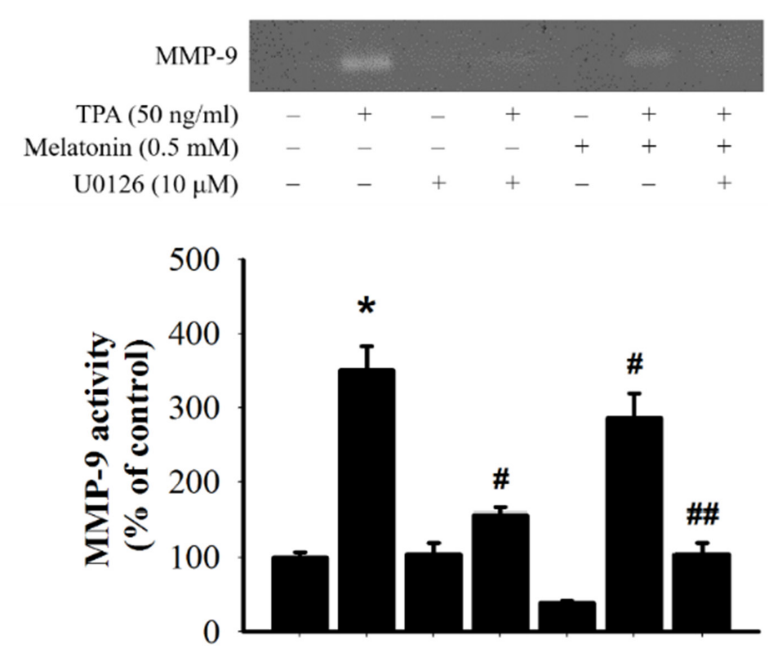

TPA $(50 \mathrm{ng} / \mathrm{ml}) \quad-\quad+\quad-\quad+\quad-\quad+\quad+$

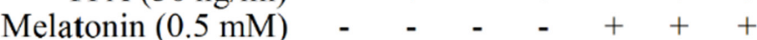
$\mathrm{U} 0126(10 \mu \mathrm{M}) \quad-\quad-\quad+\quad+\quad-\quad-\quad+$

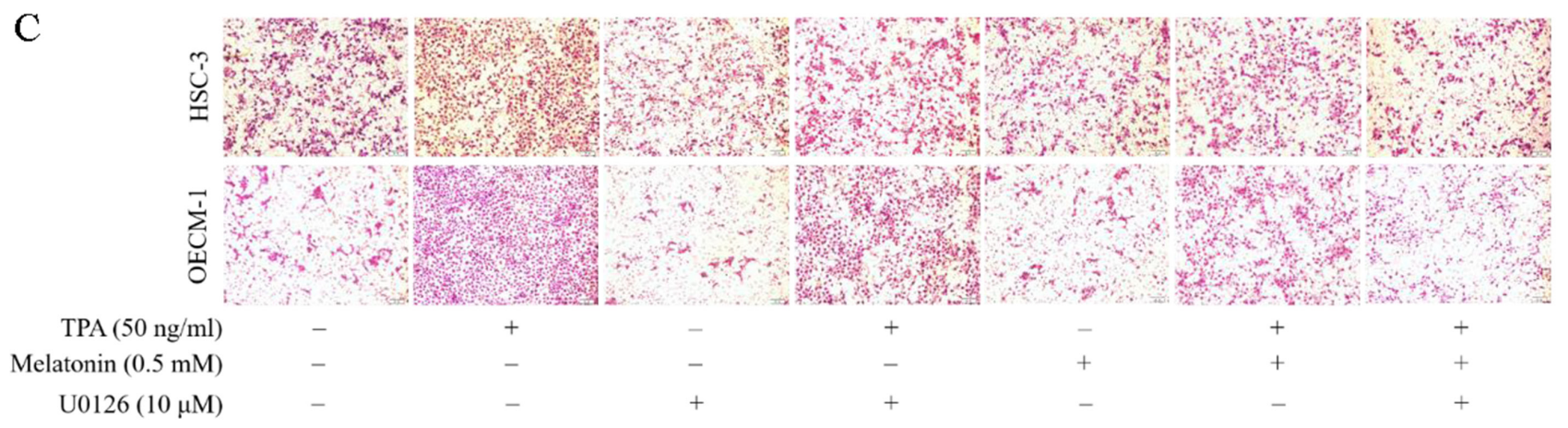

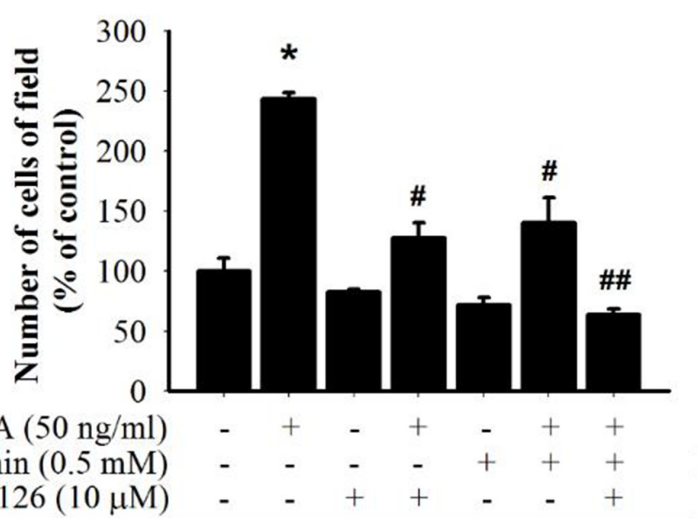
HSC-3

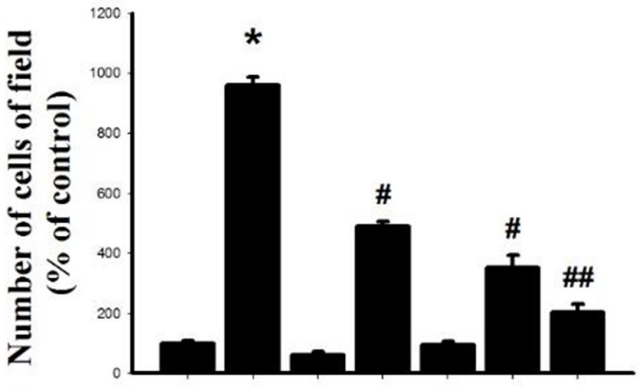

TPA $(50 \mathrm{ng} / \mathrm{ml}) \quad-\quad+\quad+\quad-\quad+\quad+$ Melatonin $(0.5 \mathrm{mM}) \quad-\quad-\quad-\quad-\quad+\quad+\quad+$ $\mathrm{U} 0126(10 \mu \mathrm{M}) \quad-\quad-\quad+\quad+\quad-\quad+$ TPA $(50 \mathrm{ng} / \mathrm{ml})$
U0126 $(10 \mu \mathrm{M})$

OECM-1

Figure 3: Effects of TPA and melatonin on the MAPK pathway. (A) HSC-3 and OECM-1 cells were treated with TPA (50 ng/mL) and melatonin $(0,0.5,1 \mathrm{mM})$ and then subjected to Western blotting to analyze the levels of ERK $1 / 2$, JNK, and p38. (B) HSC-3 and OECM-1 cells were pre-treated with U0126 $(10 \mu \mathrm{M})$ for $1 \mathrm{~h}$ and then incubated in the presence or absence of TPA $(50 \mathrm{ng} / \mathrm{mL}) \mathrm{and}$ melatonin $(0.5 \mathrm{mM})$ for $24 \mathrm{~h}$. The medium was subjected to gelatin zymography. (C) Cell migration was measured using transwell for $24 \mathrm{~h}$ (OECM-1 cell) and $48 \mathrm{~h}$ (HSC-3 cell) with polycarbonate filters, respectively. The migration abilities of HSC-3 and OECM-1 cells were quantified by counting the number of cells that invaded the underside of the porous polycarbonate. The values represented the means $\pm \mathrm{SD}$ of at least three independent experiments. ${ }^{*} p<0.05$ compared to the vehicle group; ${ }^{*} p<0.05$ compared to the TPA treatment group; ${ }^{\# \#} p<0.05$ compared to the combination of TPA and U0126, or melatonin treatment group. 
A

HSC-3 OECM-1

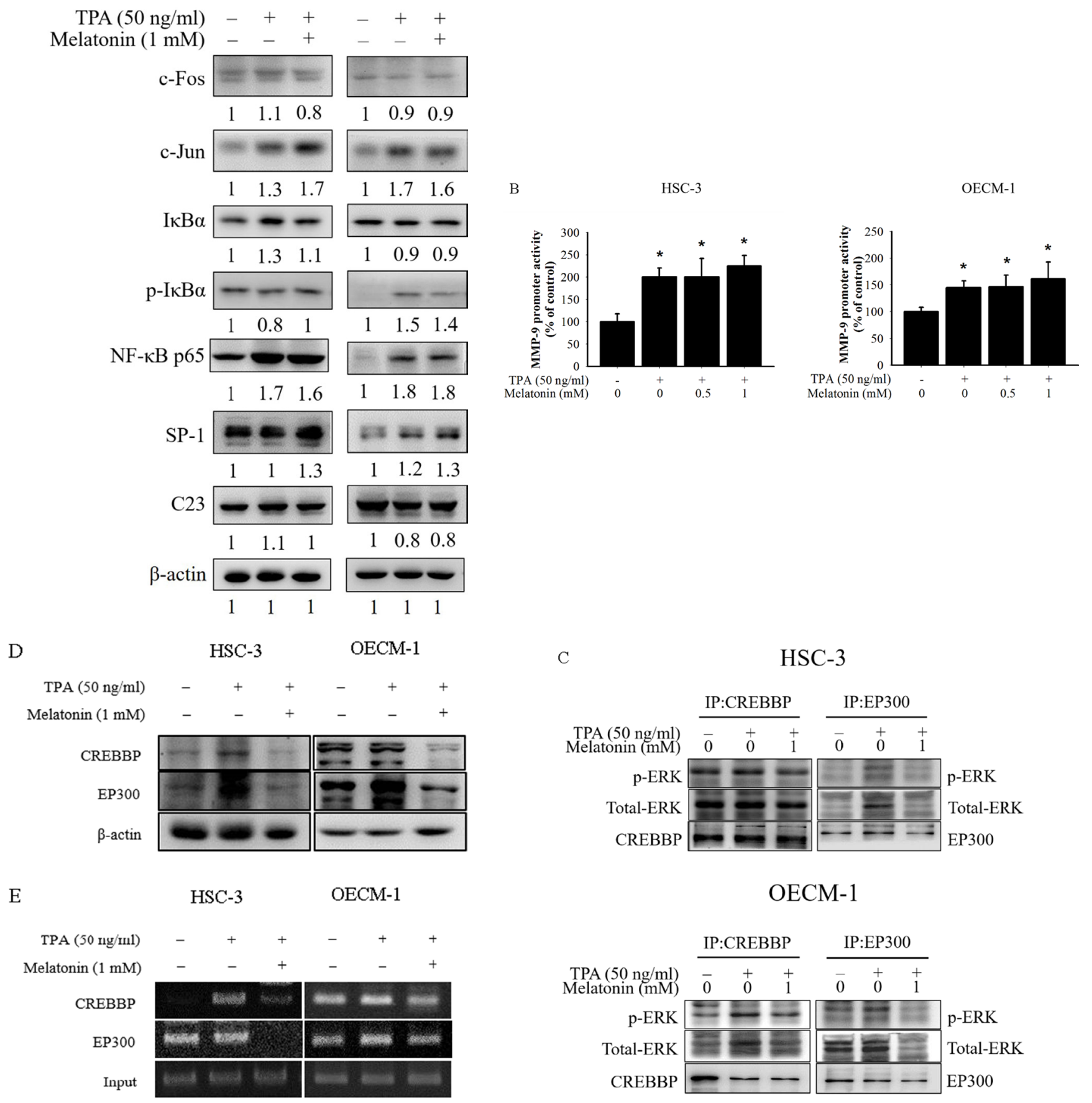

Figure 4: Effects of TPA and melatonin on the transcriptional factors and MMP-9 promoter activity. (A) HSC-3 and OECM-1cells were treated with TPA $(50 \mathrm{ng} / \mathrm{mL})$ and melatonin $(1 \mathrm{mM})$ for $24 \mathrm{~h}$ and then the nuclear fraction or total cell lysate was analyzed by western blotting. Levels of c-Fos, c-Jun, IкB $\alpha, \mathrm{NF}-\mathrm{\kappa B}$ p 65 , and SP-1 from the nucleus or total cell lysate were immunodetected with c-Fos, c-Jun, IкB $\alpha, \mathrm{NF}-\mathrm{\kappa B}$ p65, and SP-1-specific antibodies, respectively. (B) HSC-3 and OECM-1 cells were transfected with the transcriptional factors binding sites MMP-9-Luc. The transfected cells were treated with TPA $(50 \mathrm{ng} / \mathrm{mL})$ and melatonin $(0,0.5$, and $1 \mathrm{mM})$ for $24 \mathrm{~h}$. Luciferase activity, determined in triplicates, was normalized to $\beta$-galactosidase activity. The values represented the means $\pm \mathrm{SD}$ of at least three independent experiments. ${ }^{*} p<0.05$ compared to the vehicle group. (C) Nuclear extracts were immunoprecipitated (IP) with CREBBP and EP300 antibodies to analyze the interaction between ERK1/2 and CREBBP, or EP300 in vivo. Protein expressions were evaluated by western blotting. (D) The protein levels of CREBBP and EP300 were analyzed by western blotting. (E) ChIP analysis of the association of transcription coactivators, CREBBP and EP300, with the MMP-9 promoter region in HSC-3 and OECM-1 cells. 
increased the histone $\mathrm{H} 3$ and $\mathrm{H} 4$ acetylation while melatonin reduced the acetylation of histone $\mathrm{H} 3$ and $\mathrm{H} 4$ in HSC-3 and OECM-1 cells (Figure 5C). Furthermore, the binding of the acetylation of histone $\mathrm{H} 3$ and $\mathrm{H} 4$ to the MMP-9 promoter decreased in HSC-3 and OECM-1 cells following melatonin treatment by ChIP assay (Figure 5D). Overall, these findings indicated that melatonin might induce transcriptional inhibition of MMP-9 in HSC-3 cells by suppressing the CREBBP and EP300 expression and histone acetylation.

\section{CREBBP and EP300 are the key regulators for the transcriptional inhibition of MMP-9 through histone acetylation by melatonin}

To further support our findings, we examined the MMP-9 expression in The Cancer Genome Atlas (TCGA) Data Portal from Broad GDAC Firehose to determine whether MMP-9 was involved in the development of head and neck squamous cell carcinoma (HNSCC) and found that MMP-9 exhibits a higher expression in tumours than in various tumours (Figure 6A). The MMP-9 expression was significantly increased in cancer tissue compared with that in the normal parts in HNSCC (Figure 6B). To

HSC-3
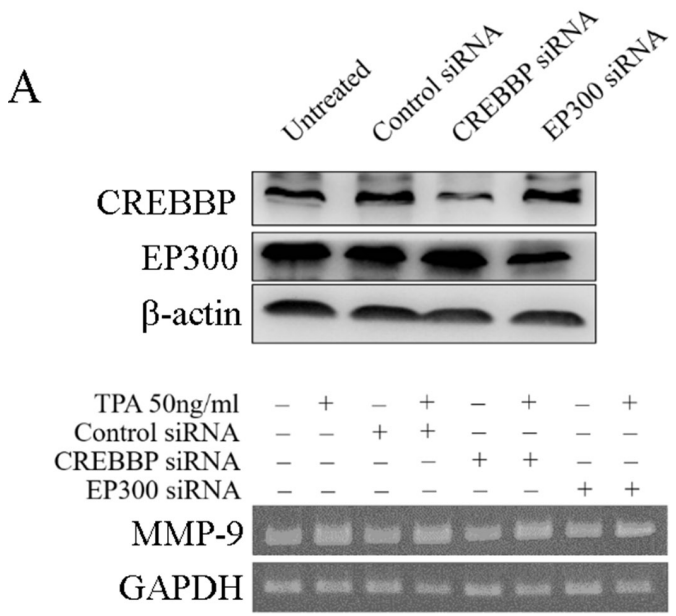

Real-time PCR

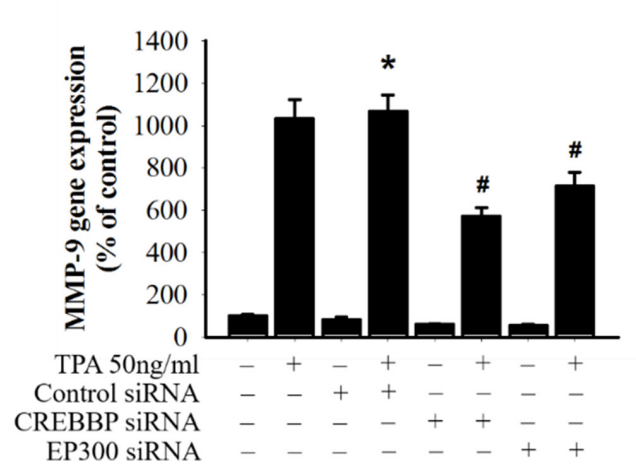

further support this conclusion, we also examined the expression of MMP-9, CREBBP, and EP300 in HNSCC tissue and their corresponding noncancerous tissue by using the TCGA Data Portal. The results demonstrated that MMP-9, CREBBP, and EP300 were significantly increased in HNSCC tissue (Figure 6C). Moreover, the relative CREBBP levels were positively correlated with the expression of MMP-9 and EP300 mRNAs in HNSCC. A significant correlation was found between CREBBP and EP300 (Spearman rank correlation coefficient $r=0.64$, $p<0.001)$ as well as MMP-9 $(r=0.46, p<0.001)$ (Figure 6D).

\section{DISCUSSION}

Numerous studies have revealed that melatonin possesses antitumour effects, including regulating cancer cell apoptosis, angiogenesis, and metastasis [34, 35]. The antitumour and antimetastatic activities of melatonin against human cancer cells have been demonstrated previously; however, few data regarding the effects of melatonin on oral cancer metastasis and the mechanisms of these effects are available. We demonstrated that melatonin inhibits migration of HSC-3 and OECM-1 oral cancer
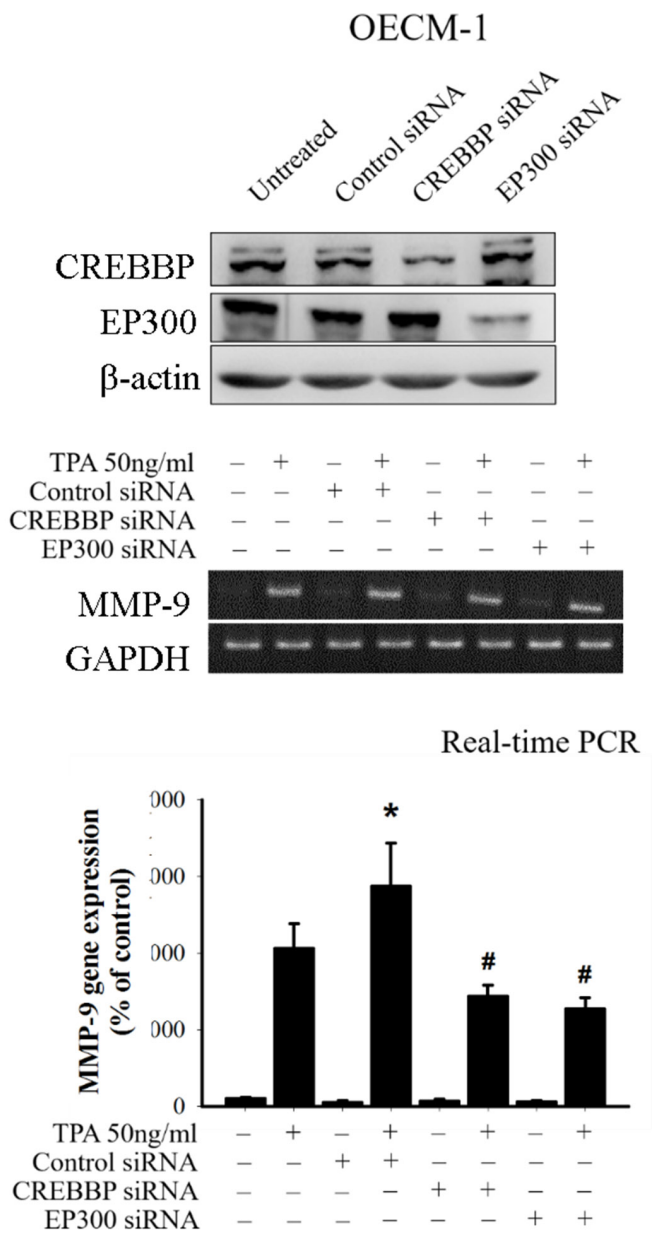

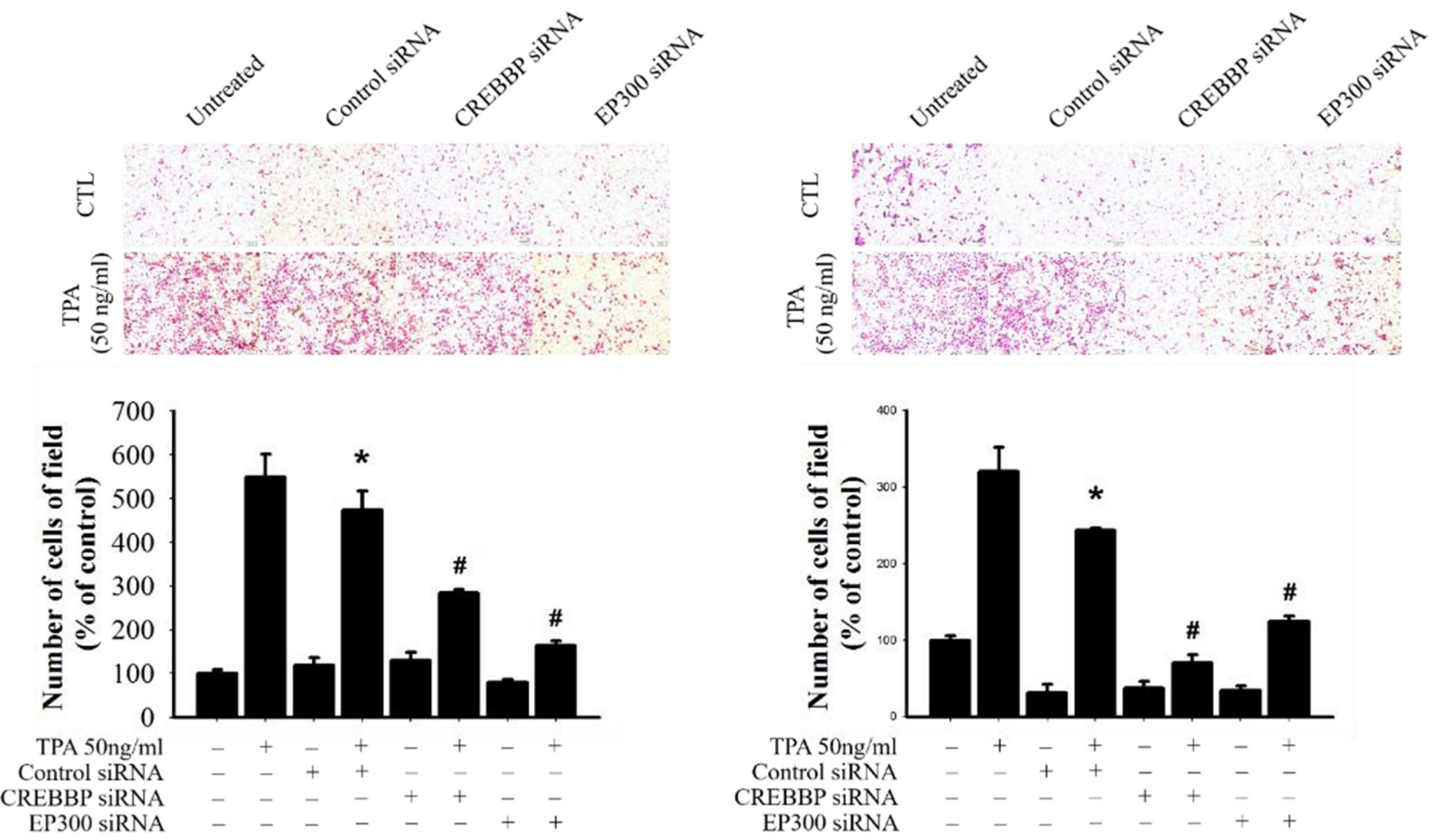

C

HSC-3 OECM-1

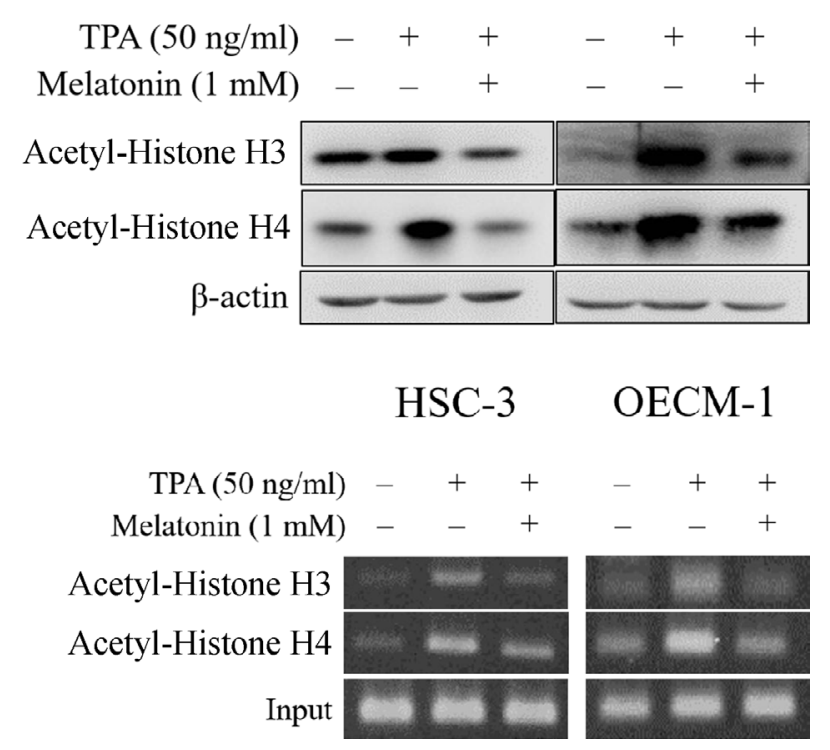

Figure 5: Critical role of CREBBP and EP300 in TPA-induced transcriptional inhibition of MMP-9 in HSC-3 and OECM-1 cells. (A) HSC-3 and OECM-1 cells were transfected with the CREBBP and EP300 siRNA, and then treated with TPA (50 ng/mL) for $24 \mathrm{~h}$. MMP-9 mRNA levels were determined by RT-PCR and real-time PCR. (B) Cell migration was measured using transwell for $24 \mathrm{~h}$ (OECM-1 cell) and $48 \mathrm{~h}$ (HSC-3 cell) with polycarbonate filters, respectively. The values represented the means \pm SD of at least three independent experiments. ${ }^{*} p<0.05$ compared to the vehicle group; ${ }^{*} p<0.05$ compared to the TPA treatment group. (C) HSC-3 and OECM-1 cells were treated with TPA $(50 \mathrm{ng} / \mathrm{mL})$ and melatonin $(1 \mathrm{mM})$ and then subjected to Western blotting to analyze the levels of Ac-H3 and Ac-H4. (D) ChIP analysis of the association of histone H3 and H4 acetylation with the MMP-9 promoter region in HSC-3 and OECM-1 cells. 
cells, inhibits the gene expression and enzyme activity of MMP-9, inhibits phosphorylation of ERK1/2, inhibits the expression of CREBBP and EP300 transcription factors, and reduces histone acetylation on the MMP-9 gene.

Metastasis involves complex and redundant pathways, including the microenvironmental interaction at the primary site, ECM degradation and growth at a distant site [36]. In this study, melatonin inhibited the migration of HSC-3 and OECM-1 oral cancer cells (Figure 1B). The critical step for invasion and metastasis is the breakdown of the basement membrane, which requires the activation of proteolytic enzymes, such as MMPs [37, 38]; Previous studies have revealed that downregulation, the activity of MMPs, can provide early targets for preventing cancer metastasis [9, 39]. In this study, the MMP-9 expression was induced by TPA, a potent tumour promoter used for studying cancer metastasis that can induce MMP-9 expression and promote cancer cell metastasis [40]. The zymography and Western blotting data in this study indicated that melatonin significantly inhibited the MMP-9 enzyme activity and protein expression in HSC-3 and OECM-1 cells (Figure 2A and 2B). Our results indicated that MMP-9 is a critical target of melatonin for regulation of oral cancer metastasis.

MAPK is a family of serine/threonine kinases, including ERK1/2, JNKs, and p38. Activation of MAPKs is followed by phosphorylation of various cytosolic substrates that participate in numerous cellular activities, such as cell proliferation, differentiation, invasion, migration, and death [41]. Activating the MAPK pathway is crucial for inducting MMP-9 expression in various cancer cell lines [42, 43], and suppressing the MAPK signalling pathway can reduce MMP expression $[5,44]$. This study revealed that melatonin inhibits the TPA-induced MMP-9 expression of oral cancer HSC-3 and OECM-1 cells through ERK1/2 phosphorylation (Figure 3A). However, Mao et al. revealed that melatonin inhibits breast cancer cell invasion by downregulating the p38 pathway [45]. Moreover, Zhou et al. found that melatonin inhibits the migration of human lung adenocarcinoma cell lines involving JNK1/2 pathway [46]. Therefore, we speculate that the effects of melatonin on MMP-9 can differ depending on the stimulus and the cancer cell line.

Regulation of MMP-9 expression occurs primarily through transcriptional, posttranscriptional, protein modification and cell surface localisation [29, 47]. Previous studies have indicated that MMP-9 inhibition is followed by the regulation of MMP-9 promoter activity by transcription factors, such as NF- $\kappa \mathrm{B}, \mathrm{AP}-1$, and SP-1 $[29,48-50]$. In this study, melatonin significantly inhibited MMP-9 mRNA expression (Figure 2C). However, the activity of the MMP-9 promoter and its transcriptional factors was not inhibited by melatonin (Figure 4A and 4B). The results of this study indicated that the TPA-induced
MMP-9 melatonin inhibition may not have occurred through transcription factors $(\mathrm{NF}-\kappa \mathrm{B}, \mathrm{AP}-1$, and SP-1) but through other transcriptional mechanisms. Gene transcription is regulated by sequence-specific transcription factors and the interaction of transcription factors and coactivators [51]. Previous studies have observed that the regulation of histone acetylation by the CREBBP and EP300 transcription coactivators is associated with MMP-9 gene transcription [52, 53]. Moreover, Ma et al. reported that histone $\mathrm{H} 3$ and $\mathrm{H} 4$ acetylation is linked to the transcriptional activation of MMP-9, which is driven by mitogen signalling in HeLa cells [54]. Thus, CREBBP and EP300 may be crucial in MMP-9 gene transcription [52, 53]. Moreover, previous studies have observed that ERK1/2 pathways are associated with regulating the expression of transcriptional coactivators CREBBP and EP300 [30, 31]. Therefore, we hypothesise that melatonin inhibits TPA-induced MMP-9 expression in oral cancer cells by regulating the coactivator family through the ERK1/2 signalling pathway. The immunoprecipitated assay revealed that melatonin-repressed ERK phosphorylation connects to the CREBBP/EP300 coactivator family (Figure 4C), and the Western blotting and ChIP results demonstrated that the expression of the CREBBP/EP300 coactivator family was inhibited by melatonin (Figure 4D and 4E).

Melatonin is used widely for the concerning the daily cycle of light and darkness to body structures and possesses anti-aging effects [55-57]. It is achievable for $20 \mathrm{mM}$ melatonin clinically [58]. Moreover, a systematic review article also concluded that time to maximal plasma/serum concentration (Tmax) was approximately $50 \mathrm{~min}$ following oral immediate-release formulations of melatonin and the bioavailability of oral melatonin was approximately 15\% [59]. Thus, the experimental concentrations of Melatonin used in this study (0-1 mM) could become clinically achievable. One limitation of the present study was the lacking of animal study, which could provide additional support to our findings in this study. Moreover, the physiological relevance of the experimental concentrations of melatonin used in the in vitro study may not be calculated accurately in vivo and will be included in our future work.

In summary, our results reveal that transcriptional suppression of the MMP-9 gene occurred through the downregulation of ERK1/2 signalling pathways, resulting in the decreased expression of CREBBP and EP300, which inhibited histone acetylation on the MMP-9 promoter (Figure 6E). Furthermore, these mechanisms interfere with the assembly of functional transcription complexes on the MMP-9 promoter, but the recruitment of transcription factors, such as NF- $\mathrm{KB}, \mathrm{AP}-1$, and Sp-1, is not affected by melatonin. Thus, inhibition of oral cancer metastasis by melatonin can provide crucial preventive and therapeutic protection against oral cancer. 

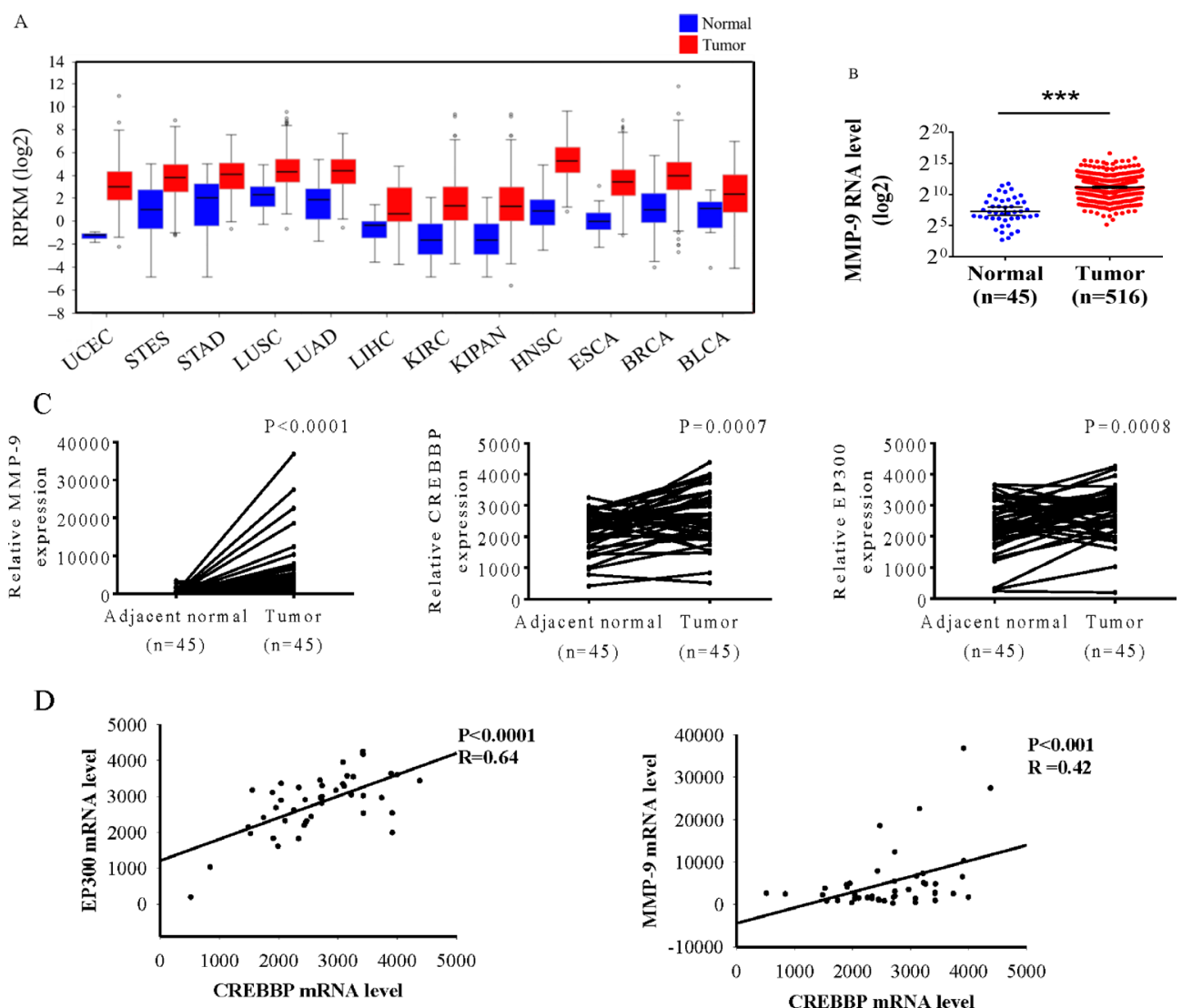

$\mathrm{E}$
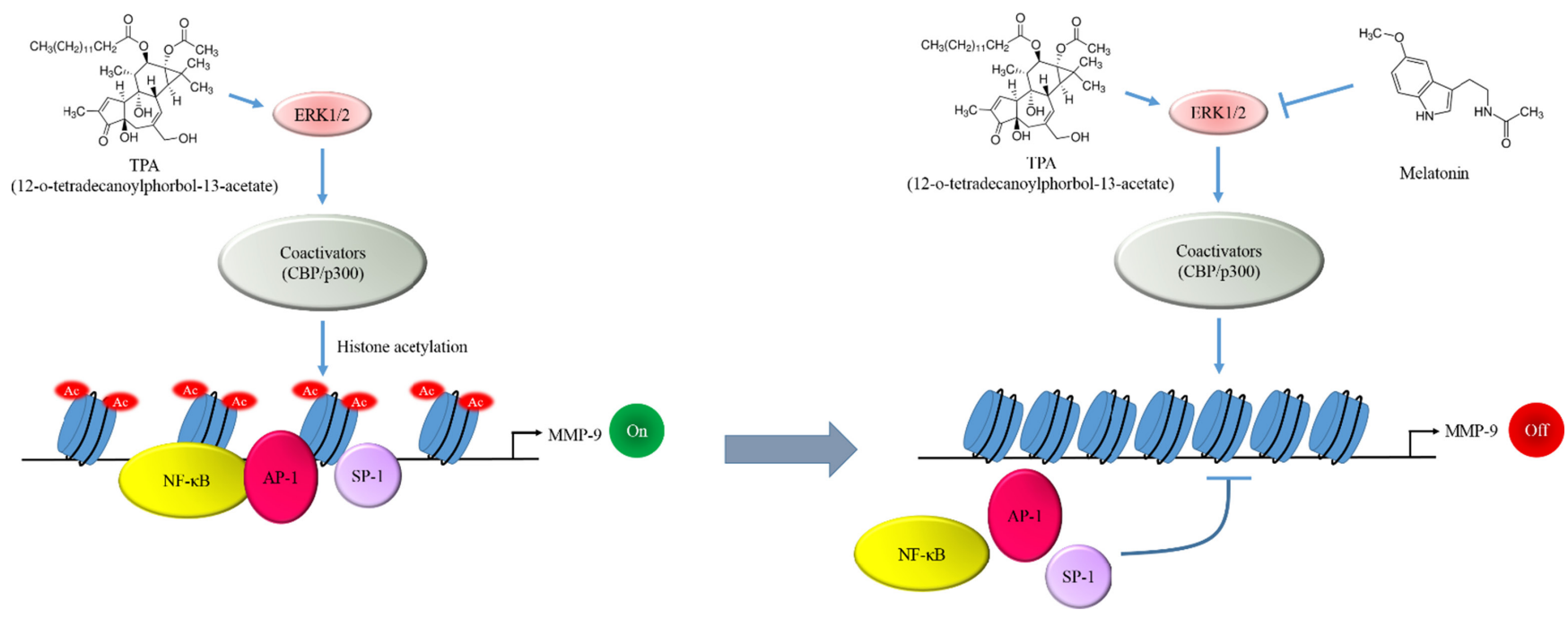

Figure 6: Levels of MMP-9, CREBBP, and EP300 are increased in head and neck squamous cell carcinoma samples. (A) The expression of MMP-9 among 12 cancer types from The Cancer Genome Atlas (TCGA) Data Portal from Broad GDAC Firehose data portal. The mRNA RPKM (Reads per Kilobase of exon model per Million) reads per million mappable reads of all samples were selected and analyzed for comparing abundances by the website of Broad GDAC Firehose. (B) The expression of MMP-9 in normal and head and neck squamous cell carcinoma from TCGA Data Portal. $* * * p<0.05$. (C) Relative expression of MMP-9, CREBBP, and EP300 in 45 pairs of head and neck squamous cell carcinoma tumor tissues and their corresponding adjacent non-cancerous tissues. (D) The correlations among mRNA levels of CREBBP and EP300 as well as MMP-9 in head and neck squamous cell carcinoma. A significant correlation was found between CREBBP and EP300 (Spearman rank correlation coefficient $r=0.64, p<0.001)$ as well as MMP-9 $(r=0.46, p<0.001)$. (E) A model depicting reciprocal regulation between melatonin and MMP-9 transcription in oral cancer. UCEC: uterine corpus endometrial carcinoma. STES: stomach and esophageal carcinoma. STAD: stomach adenocarcinoma. LUSC: lung squamous cell carcinoma. LUAD: lung adenocarcinoma. LIHC: liver hepatocellular carcinoma. KIRC: kidney renal clear cell carcinoma. KIPAN: pan-kidney cohort. HNSC: head and neck squamous cell carcinoma. ESCA: esophageal carcinoma. BRCA: breast invasive carcinoma. BLCA: bladder cancer. 


\section{MATERIALS AND METHODS}

\section{Cell and cell culture}

Human oral squamous cell carcinoma (OSCC) cell line HSC-3 cells were purchased from and validated by the Japanese Collection of Research Bioresources Cell Bank (JCRB, Shinjuku, Japan) and were cultured in DMEM/F-12 or RPMI-1640 medium (Life Technologies, Grand Island, NY), 10\% fetal bovine serum (FBS), $2 \mathrm{mM}$ glutamine, $100 \mathrm{U} / \mathrm{ml}$ penicillin, and $100 \mu \mathrm{g} / \mathrm{ml}$ streptomycin. Oral epidermal carcinoma cell line OECM-1 cells were obtained from Dr Meng's group where the cell line is originally established and authenticated [60] and maintained in RPMI (Gibco) supplemented with $10 \%$ FBS. All cell cultures were maintained at $37^{\circ} \mathrm{C}$ in a humidified atmosphere of $5 \% \mathrm{CO} 2$. For melatonin treatment, appropriate amounts of stock solution of melatonin were added into the culture medium to achieve the indicated concentrations. The cells were then incubated for the indicated time periods. Dimethyl sulfoxide solution without melatonin was used as blank reagent.

\section{Analysis of cell viability (MTT assay)}

To evaluate the cytotoxicity of melatonin, an MTT colorimetric assay was performed to determine cell viability. OECM-1 and HSC-3 were seeded in 24-well plates at a density of $9 \times 10^{4}$ or $1.2 \times 10^{5}$ cells per well and treated with $0,0.5$ and $1 \mathrm{mM}$ of melatonin at $37^{\circ} \mathrm{C}$ in $5 \% \mathrm{CO} 2$ for $24 \mathrm{~h}$. At the end of the exposure period, the cells were washed with PBS and incubated with $0.8 \mathrm{~mL}$ of MTT (Sigma chemical Co., St. Louis, MO, USA) per well (final concentration, $0.5 \mathrm{mg} / \mathrm{mL}$ ) at $37^{\circ} \mathrm{C}$ in $5 \% \mathrm{CO} 2$ for $4 \mathrm{~h}$. The viable cell number was directly proportional to the production of formazan following solubilization with isopropanol, which was measured spectrophotometrically at $563 \mathrm{~nm}$ (Beckman Spectrophotometer DU640, Beckman Instruments, and Fullerton, CA, USA).

\section{Cell migration assays}

Cell migration was assayed according to the methods described by Lin et al. [3]. After treatment with for $24 \mathrm{~h}$, the surviving HSC-3 and OECM-1 cells were harvested and seeded to a Transwell (Costar, Corning, NY, USA) at $4 \times 10^{4}$ cells per well in $0.5 \%$ fetal bovine serum medium, and then incubated for $24 \mathrm{~h}$ or $40 \mathrm{~h}$ at $37^{\circ} \mathrm{C}$. The migrating cells were fixed with methanol and stained with Giemsa. The cell numbers were counted by light microscopy.

\section{Determination of MMP-9 activity by zymography}

The activities of MMP-9 in the conditional medium were measured by gelatin zymography protease assays as previously described [61]. Briefly, collected media of an appropriate volume were prepared with SDS sample buffer without boiling or reduction, and subjected to $0.1 \%$ gelatin- $8 \%$ SDS-PAGE electrophoresis. After electrophoresis, the gels were washed with $2.5 \%$ Triton $\mathrm{X}-100$ and incubated in a reaction buffer $(40 \mathrm{mM}$ Tris$\mathrm{HCl}, \mathrm{pH} 8.0 ; 10 \mathrm{mM} \mathrm{CaCl} 2$ and $0.01 \% \mathrm{NaN} 3$ ) at $37^{\circ} \mathrm{C}$ for $12 \mathrm{~h}$. The gel was stained with Coomassie brilliant blue $\mathrm{R}-250$ for visualization.

\section{Western blotting analysis for determining molecular pathway}

Total cell lysates or nuclear extracts were prepared as previously described [3]. The cell lysates were separated in a $10 \%$ polyacrylamide gel and transferred onto a nitrocellulose membrane. The blot was subsequently incubated with $5 \%$ non-fat milk in Tris-buffered saline (20 mM Tris, $137 \mathrm{mM} \mathrm{NaCl}, \mathrm{pH}$ 7.6) for $1 \mathrm{~h}$ to block non-specific binding, and then overnight with polyclonal antibodies against three MAPKs (ERK 1/2, JNK 1/2, and p38), CREBBP, EP300, acetyl-Histone-H3, acetylHistone-H4 and $\beta$-actin with the specific antibodies for unphosphorylated or phosphorylated forms. The blots were then incubated with horseradish peroxidase goat antirabbit or anti-mouse IgG for $1 \mathrm{~h}$. Signal was detected by using an enhanced chemiluminescence (ECL) commercial kit (Amersham Biosciences, Piscataway, NJ, USA). The relative photographic density was quantitated by scanning the photographic negatives on a gel documentation and analysis system (AlphaImager 2000, Alpha Innotech Corporation, and San Leandro, CA, USA).

\section{RNA preparation, semi-quantitative RT-PCR, TaqMan quantitative real-time PCR}

Total RNA was isolated from cancer cells using Total RNA mini kit (Geneaid). For Semi-quantitative RT-PCR, the PCR was performed in a reaction mixture containing $2 \mu \mathrm{L}$ cDNA, $0.2 \mathrm{mM}$ dNTP mixture, $2 \mu \mathrm{M}$ of each primers, $1 \mathrm{U}$ Taq DNA polymerase, and 1-fold concentration of Thermal Pol Buffer (New England BioLabs, MA, USA). The specific primer sequences for these genes are as following: MMP-9: 5'-CAACATCACCTATTGGATCC-3' (forward), 5'- CGG GTGTAGAGTCTCTCGCT-3'(reverse), and GAPDH: 5'AGCCTTCTCCATGGTTGGTGAAGAC-3' (forward), 5'- CGGAGTCAACGGATTTGGTCGTAT-3' (reverse). Moreover, quantitative real-time PCR analysis was performed using TaqMan one-step PCR Master Mix 
(Applied Biosystems, Foster City, CA, USA). Total cDNA $(2 \mu \mathrm{g})$ was added per $9 \mu \mathrm{l}$ reactions with MMP-9 or GAPDH primers and TaqMan probes. The MMP-9 (Hs00234579_m1) and GAPDH (Hs99999905_m1) primers and probes were designed using commercial software (ABI PRISM Sequence Detection System; Applied Biosystems, Foster City, CA, USA). Quantitative real-time PCR assays were conducted in triplicate on a StepOnePlus sequence detection system. Threshold was set above the non-template control background and within the linear phase of target gene amplification to calculate the cycle number at which the transcript was detected [3].

\section{Transfection and MMP-9 promoter-driven luciferase assays}

The HSC-3 and OECM-1 cells were seeded at a concentration of $10^{5}$ or $1.4 \times 10^{5}$ cells per well in 24well cell culture plates. After $12 \mathrm{~h}$ of incubation, pGL3basic (vector) and MMP-9 promoter plasmid were co-transfected with a $\beta$-galactosidase expression vector (pCH110) into cells using Turbofect (Fermentas, Carlsbad, $\mathrm{CA}$ ) as previously described [5]. After $24 \mathrm{~h}$ of transfection, the cells were treated with vehicle or melatonin $(0-1 \mathrm{mM})$ for $24 \mathrm{~h}$. The cell lysates were harvested and luciferase activity was determined using a luciferase assay kit. The value of the luciferase activity was normalized to transfection efficiency and monitored by $\beta$-galactosidase expression.

\section{Chromatin immunoprecipitation analysis (ChIP)}

Chromatin immunoprecipitation analysis was performed as described previously by Yang et al.[5]. In brief, chromatin and proteins from approximate $1 \times 10^{6}$ cells were crosslinked with $1 \%$ formaldehyde for $10 \mathrm{~min}$ at room temperature. These cells were collected, lysed, and sonicated on ice to shear the chromatin DNA to a length between $200-1000$ base pair by using Sonicator 3000 (Misonix, NY, USA). DNA immunoprecipitated with anti-CREBBP, anti-EP300, anti-acetyl-histone-H3 or anti-acetyl-histone-H4 was purified and extracted using PCR purification kit (QIAGEN, Redwood City, CA, USA).

\section{Immunoprecipitation assay (IP)}

Immunoprecipitation analysis was modified as described previously by Meissner et al.[31]. In brief, cell lysates were immunoprecipitated with $50 \mu \mathrm{l}$ of Protein A conjugated with CREBBBP and EP300 antibodies affinity matrix-conjugated individually in NET-N buffer [1M Tris-Hcl ( $\mathrm{pH} 8.0$ ), 0.5 M EDTA, $5 \mathrm{M} \mathrm{Nacl}$, and 0.5\% Nonidet P-40] under gentle shaking at $4{ }^{\circ} \mathrm{C}$ overnight. Immunoprecipitated beads were pelleted and washed three times with $1 \mathrm{ml}$ of NET-N buffer. Protein was removed from the beads by boiling in 2X SDS loading buffer for $5 \mathrm{~min}$ and separated by SDS-PAGE, followed by western blotting, probed with phospho-ERK1/2 antibodies, or as indicated.

\section{Statistical analysis}

Statistically significant differences were calculated using the Student's $t$-test (SigmaPlot 10.0, Jandel Scientific, and San Rafael, CA, USA). Significance was set at $p<0.05$. The values are the means \pm standard deviation (SD) of at least three independent experiments.

\section{ACKNOWLEDGMENTS}

This work was supported in part by grants from the Ministry of Science and Technology, Taiwan (MOST103-2632-B-040-001 and MOST-104-2632-B-040-001). This study was also supported by a grant from Chung Shan Medical University Hospital, Taiwan (CSH-2015E-001-Y2).

\section{CONFLICTS OF INTEREST}

The authors have declared that no competing interests exist.

\section{Authors' contributions}

Yang SF and Lin CW designed and conceived the study. Yeh CM, Yang JS, and Yang WE performed the in vitro experiments. Yeh $\mathrm{CM}$ and $\mathrm{Su} \mathrm{SC}$ analysed the clinical data. Yeh CM and Yang SF drafted the manuscript.

\section{REFERENCES}

1. Jemal A, Siegel R, Ward E, Hao Y, Xu J, Thun MJ. Cancer statistics, 2009. CA Cancer J Clin. 2009; 59:225-249.

2. Ichikawa Y, Ishikawa T, Tanaka K, Togo S, Shimada H. [Extracellular matrix degradation enzymes: important factors in liver metastasis of colorectal cancer and good targets for anticancer metastatic therapy]. [Article in Japanese]. Nihon Geka Gakkai Zasshi. 2001; 102:376-380.

3. Lin CW, Chou YE, Chiou HL, Chen MK, Yang WE, Hsieh MJ, Yang SF. Pterostilbene suppresses oral cancer cell invasion by inhibiting MMP-2 expression. Expert Opin Ther Targets. 2014; 18:1109-1120.

4. Weng CJ, Chen MK, Lin CW, Chung TT, Yang SF. Single nucleotide polymorphisms and haplotypes of MMP-14 are associated with the risk and pathological development of oral cancer. Ann Surg Oncol. 2012; 19:S319-327. 
5. Yang SF, Lee WJ, Tan P, Tang CH, Hsiao M, Hsieh FK, Chien MH. Upregulation of miR-328 and inhibition of CREBDNA-binding activity are critical for resveratrol-mediated suppression of matrix metalloproteinase-2 and subsequent metastatic ability in human osteosarcomas. Oncotarget. 2015; 6:2736-2753. doi: 10.18632/oncotarget.3088.

6. Gao ZB, Duan YQ, Zhang L, Chen DW, Ding PT. Expression of matrix metalloproteinase 2 and its tissue inhibitor in oral squamous cell carcinoma. Int J Mol Med. 2005; 16:599-603.

7. Shah FD, Shukla SN, Shah PM, Shukla HK, Patel PS. Clinical significance of matrix metalloproteinase 2 and 9 in breast cancer. Indian J Cancer. 2009; 46: 194-202.

8. Lotfi A, Mohammadi G, Saniee L, Mousaviagdas M, Chavoshi H, Tavassoli A. Serum Level of Matrix Metalloproteinase-2 and -9 in Patients with Laryngeal Squamous Cell Carcinoma and Clinical Significance. Asian Pac J Cancer Prev. 2015; 16:6749-6751.

9. Chien MH, Lin CW, Cheng CW, Wen YC, Yang SF. Matrix metalloproteinase-2 as a target for head and neck cancer therapy. Expert Opin Ther Targets. 2013; 17:203-216.

10. Chao R, Chow JM, Hsieh YH, Chen CK, Lee WJ, Hsieh FK, Yu NY, Chou MC, Cheng CW, Yang SF, Chien MH. Tricetin suppresses the migration/invasion of human glioblastoma multiforme cells by inhibiting matrix metalloproteinase-2 through modulation of the expression and transcriptional activity of specificity protein 1 . Expert Opin Ther Targets. 2015; 19:1293-1306.

11. Chien SY, Hsieh MJ, Chen CJ, Yang SF, Chen MK. Nobiletin inhibits invasion and migration of human nasopharyngeal carcinoma cell lines by involving ERK1/2 and transcriptional inhibition of MMP-2. Expert Opin Ther Targets. 2015; 19:307-320.

12. Lin CW, Chen PN, Chen MK, Yang WE, Tang CH, Yang SF, Hsieh YS. Kaempferol reduces matrix metalloproteinase-2 expression by down-regulating ERK1/2 and the activator protein-1 signaling pathways in oral cancer cells. PLoS One. 2013; 8:e80883.

13. Lin FY, Hsieh YH, Yang SF, Chen CT, Tang CH, Chou MY, Chuang YT, Lin CW, Chen MK. Resveratrol suppresses TPA-induced matrix metalloproteinase-9 expression through the inhibition of MAPK pathways in oral cancer cells. J Oral Pathol Med. 2015; 44:699-706.

14. Acuna-CastroviejoD, Escames G, Venegas C, Diaz-Casado ME, Lima-Cabello E, Lopez LC, Rosales-Corral S, Tan DX, Reiter RJ. Extrapineal melatonin: sources, regulation, and potential functions. Cell Mol Life Sci. 2014; 71:2997-3025.

15. Calvo JR, Gonzalez-Yanes C, Maldonado MD. The role of melatonin in the cells of the innate immunity: a review. J Pineal Res. 2013; 55:103-120.

16. Zhang HM, Zhang Y. Melatonin: a well-documented antioxidant with conditional pro-oxidant actions. J Pineal Res. 2014; 57:131-146.
17. Manchester LC, Coto-Montes A, Boga JA, Andersen LP, Zhou Z, Galano A, Vriend J, Tan DX, Reiter RJ. Melatonin: an ancient molecule that makes oxygen metabolically tolerable. J Pineal Res. 2015; 59:403-419.

18. Loureiro R, Magalhaes-Novais S, Mesquita KA, Baldeiras I, Sousa IS, Tavares LC, Barbosa IA, Oliveira PJ, Vega-Naredo I. Melatonin antiproliferative effects require active mitochondrial function in embryonal carcinoma cells. Oncotarget. 2015; 6:17081-17096. doi: 10.18632/oncotarget.4012.

19. Vriend J, Reiter RJ. Breast cancer cells: Modulation by melatonin and the ubiquitin-proteasome system - a review. Mol Cell Endocrinol. 2015; 417:1-9.

20. Reiter RJ, Rosales-Corral SA, Liu XY, Acuna-Castroviejo D, Escames G, Tan DX. Melatonin in the oral cavity: physiological and pathological implications. J Periodontal Res. 2015; 50:9-17.

21. Mao L, Dauchy RT, Blask DE, Slakey LM, Xiang S, Yuan L, Dauchy EM, Shan B, Brainard GC, Hanifin JP, Frasch T, Duplessis TT, Hill SM. Circadian gating of epithelialto-mesenchymal transition in breast cancer cells via melatonin-regulation of GSK3beta. Mol Endocrinol. 2012; 26:1808-1820.

22. Jardim-Perassi BV, Arbab AS, Ferreira LC, Borin TF, Varma NR, Iskander AS, Shankar A, Ali MM, de Campos Zuccari DA. Effect of melatonin on tumor growth and angiogenesis in xenograft model of breast cancer. PLoS One. 2014; 9:e85311.

23. Wang Z, Dabrosin C, Yin X, Fuster MM, Arreola A, Rathmell WK, Generali D, Nagaraju GP, El-Rayes B, Ribatti D, Chen YC, Honoki K, Fujii H, et al. Broad targeting of angiogenesis for cancer prevention and therapy. Semin Cancer Biol. 2015; 35:S224-43. doi: 10.1016/j. semcancer.2015.01.001.

24. Swarnakar S, Paul S, Singh LP, Reiter RJ. Matrix metalloproteinases in health and disease: regulation by melatonin. J Pineal Res. 2011; 50:8-20.

25. Rudra DS, Pal U, Maiti NC, Reiter RJ, Swarnakar S. Melatonin inhibits matrix metalloproteinase- 9 activity by binding to its active site. J Pineal Res. 2013; 54:398-405.

26. Zhang Y, Liu Q, Wang F, Ling EA, Liu S, Wang L, Yang Y, Yao L, Chen X, Wang F, Shi W, Gao M, Hao A. Melatonin antagonizes hypoxia-mediated glioblastoma cell migration and invasion via inhibition of HIF-1alpha. J Pineal Res. 2013; 55:121-130.

27. Ordonez R, Carbajo-Pescador S, Prieto-Dominguez N, Garcia-Palomo A, Gonzalez-Gallego J, Mauriz JL. Inhibition of matrix metalloproteinase-9 and nuclear factor kappa B contribute to melatonin prevention of motility and invasiveness in HepG2 liver cancer cells. J Pineal Res. 2014; 56:20-30.

28. Goncalves Ndo N, Rodrigues RV, Jardim-Perassi BV, Moschetta MG, Lopes JR, Colombo J, Zuccari DA. Molecular markers of angiogenesis and metastasis in lines of oral carcinoma after treatment with melatonin. Anticancer Agents Med Chem. 2014; 14:1302-1311. 
29. Lauricella-Lefebvre MA, Castronovo V, Sato H, Seiki M, French DL, Merville MP. Stimulation of the 92-kD type IV collagenase promoter and enzyme expression in human melanoma cells. Invasion Metastasis. 1993; 13:289-300.

30. Chen YJ, Wang YN, Chang WC. ERK2-mediated C-terminal serine phosphorylation of p300 is vital to the regulation of epidermal growth factor-induced keratin 16 gene expression. J Biol Chem. 2007; 282:27215-27228.

31. Meissner JD, Freund R, Krone D, Umeda PK, Chang KC, Gros G, Scheibe RJ. Extracellular signal-regulated kinase 1/2-mediated phosphorylation of p300 enhances myosin heavy chain $\mathrm{I} /$ beta gene expression via acetylation of nuclear factor of activated $\mathrm{T}$ cells c1. Nucleic Acids Res. 2011; 39:5907-5925.

32. Sharma N, Nyborg JK. The coactivators CBP/p300 and the histone chaperone NAP1 promote transcription-independent nucleosome eviction at the HTLV-1 promoter. Proc Natl Acad Sci U S A. 2008; 105:7959-7963.

33. Pons D, de Vries FR, van den Elsen PJ, Heijmans BT, Quax PH, Jukema JW. Epigenetic histone acetylation modifiers in vascular remodelling: new targets for therapy in cardiovascular disease. Eur Heart J. 2009; 30:266-277.

34. Carbajo-Pescador S, Ordonez R, Benet M, Jover R, GarciaPalomo A, Mauriz JL, Gonzalez-Gallego J. Inhibition of VEGF expression through blockade of Hiflalpha and STAT3 signalling mediates the anti-angiogenic effect of melatonin in HepG2 liver cancer cells. Br J Cance. 2013; 109:83-91.

35. Hong Y, Won J, Lee Y, Lee S, Park K, Chang KT, Hong Y. Melatonin treatment induces interplay of apoptosis, autophagy, and senescence in human colorectal cancer cells. J Pineal Res. 2014; 56:264-274.

36. Valastyan S, Weinberg RA. Tumor metastasis: molecular insights and evolving paradigms. Cell. 2011; 147:275-292.

37. Liotta LA, Stetler-Stevenson WG. Tumor invasion and metastasis: an imbalance of positive and negative regulation. Cancer Res. 1991; 51:5054s-5059s.

38. Coussens LM, Werb Z. Matrix metalloproteinases and the development of cancer. Chem Biol. 1996; 3:895-904.

39. Okada N, Ishida H, Murata N, Hashimoto D, Seyama Y, Kubota S. Matrix metalloproteinase-2 and -9 in bile as a marker of liver metastasis in colorectal cancer. Biochem Biophys Res Commun. 2001; 288:212-216.

40. Liu JF, Crepin M, Liu JM, Barritault D, Ledoux D. FGF-2 and TPA induce matrix metalloproteinase-9 secretion in MCF-7 cells through PKC activation of the Ras/ERK pathway. Biochem Biophys Res Commun. 2002; 293:1174-1182.

41. Sun Y, Liu WZ, Liu T, Feng X, Yang N, Zhou HF. Signaling pathway of MAPK/ERK in cell proliferation, differentiation, migration, senescence and apoptosis. J Recept Signal Transduct Res. 2015; 35:600-604.

42. Simon C, Goepfert H, Boyd D. Inhibition of the p38 mitogen-activated protein kinase by SB 203580 blocks
PMA-induced Mr 92,000 type IV collagenase secretion and in vitro invasion. Cancer Res. 1998; 58:1135-1139.

43. Genersch E, Hayess K, Neuenfeld Y, Haller H. Sustained ERK phosphorylation is necessary but not sufficient for MMP-9 regulation in endothelial cells: involvement of Ras-dependent and -independent pathways. J Cell Sci. 2000; 113:4319-4330.

44. Hsu HH, Hu WS, Lin YM, Kuo WW, Chen LM, Chen WK, Hwang JM, Tsai FJ, Liu CJ, Huang CY. JNK suppression is essential for 17beta-Estradiol inhibits prostaglandin E2Induced UPA and MMP-9 expressions and cell migration in human LoVo colon cancer cells. J Biomed Sci. 2011; 18:61.

45. Mao L, Yuan L, Slakey LM, Jones FE, Burow ME, Hill SM. Inhibition of breast cancer cell invasion by melatonin is mediated through regulation of the p38 mitogen-activated protein kinase signaling pathway. Breast Cancer Res. 2010; 12:R107.

46. Zhou Q, Gui S, Zhou Q, Wang Y. Melatonin inhibits the migration of human lung adenocarcinoma A549 cell lines involving JNK/MAPK pathway. PLoS One. 2014; 9:e101132.

47. Chakraborti S, Mandal M, Das S, Mandal A, Chakraborti T. Regulation of matrix metalloproteinases: an overview. Mol Cell Biochem. 2003; 253:269-285.

48. Hah N, Lee ST. An absolute role of the PKC-dependent NFkappaB activation for induction of MMP-9 in hepatocellular carcinoma cells. Biochem Biophys Res Commun. 2003; 305:428-433.

49. Shin Y, Yoon SH, Choe EY, Cho SH, Woo CH, Rho JY, Kim JH. PMA-induced up-regulation of MMP-9 is regulated by a PKCalpha-NF-kappaB cascade in human lung epithelial cells. Exp Mol Med. 2007; 39:97-105.

50. Lin CW, Hou WC, Shen SC, Juan SH, Ko CH, Wang LM, Chen YC. Quercetin inhibition of tumor invasion via suppressing PKC delta/ERK/AP-1-dependent matrix metalloproteinase-9 activation in breast carcinoma cells. Carcinogenesis. 2008; 29:1807-1815.

51. Guarente L. Transcriptional coactivators in yeast and beyond. Trends Biochem Sci. 1995; 20:517-521.

52. Lackey DE, Hoag KA. Vitamin A upregulates matrix metalloproteinase- 9 activity by murine myeloid dendritic cells through a nonclassical transcriptional mechanism. J Nutr. 2010; 140:1502-1508.

53. Santer FR, Hoschele PP, Oh SJ, Erb HH, Bouchal J, Cavarretta IT, Parson W, Meyers DJ, Cole PA, Culig Z. Inhibition of the acetyltransferases p300 and CBP reveals a targetable function for p300 in the survival and invasion pathways of prostate cancer cell lines. Mol Cancer Ther. 2011; 10:1644-1655.

54. Ma Z, Shah RC, Chang MJ, Benveniste EN. Coordination of cell signaling, chromatin remodeling, histone modifications, and regulator recruitment in human matrix metalloproteinase 9 gene transcription. Mol Cell Biol. 2004; 24:5496-5509. 
55. Claustrat B, Leston J. Melatonin: Physiological effects in humans. Neurochirurgie. 2015; 61:77-84.

56. Jenwitheesuk A, Nopparat C, Mukda S, Wongchitrat P, Govitrapong P. Melatonin regulates aging and neurodegeneration through energy metabolism, epigenetics, autophagy and circadian rhythm pathways. Int J Mol Sci. 2014; 15:16848-16884.

57. Rizvi SI, Jha R. Strategies for the discovery of anti-aging compounds. Expert Opin Drug Discov. 2011; 6:89-102.

58. Berk L, Berkey B, Rich T, Hrushesky W, Blask D, Gallagher M, Kudrimoti M, McGarry RC, Suh J, Mehta M. Randomized phase II trial of high-dose melatonin and radiation therapy for RPA class 2 patients with brain metastases (RTOG 0119). Int J Radiat Oncol Biol Phys. 2007; 68:852-857.

59. Harpsoe NG, Andersen LP, Gogenur I, Rosenberg J. Clinical pharmacokinetics of melatonin: a systematic review. Eur J Clin Pharmacol. 2015; 71:901-909.

60. Yang CY, Meng CL. Regulation of PG synthase by EGF and PDGF in human oral, breast, stomach, and fibrosarcoma cancer cell lines. J Dent Res. 1994; 73: 1407-1415.

61. Yang SF, Chu SC, Chiang IC, Kuo WF, Chiou HL, Chou FP, Kuo WH, Hsieh YS. Excessive matrix metalloproteinase-9 in the plasma of community-acquired pneumonia. Clin Chim Acta. 2005; 352:209-215. 